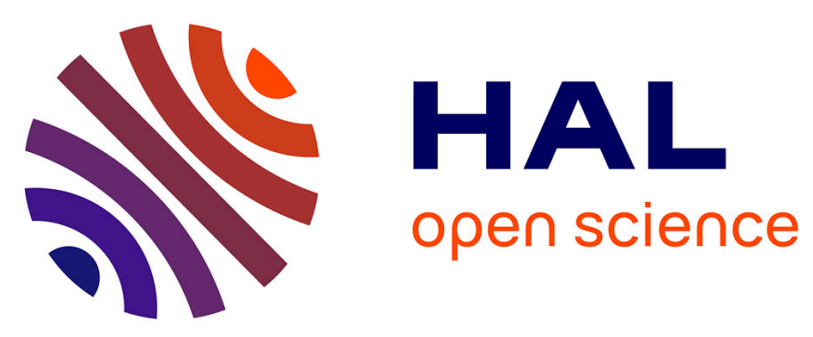

\title{
Incidence and survival of peritoneal malignant mesothelioma between 1989 and 2015: A population-based study
}

Nolwenn Le Stang, Véronique Bouvier, Olivier Glehen, Laurent Villeneuve, Françoise Galateau-Sallé, Bénédicte Clin

\section{To cite this version:}

Nolwenn Le Stang, Véronique Bouvier, Olivier Glehen, Laurent Villeneuve, Françoise Galateau-Sallé, et al.. Incidence and survival of peritoneal malignant mesothelioma between 1989 and 2015: A population-based study. Cancer Epidemiology, 2019, 60, pp.106-111. 10.1016/j.canep.2019.03.014 . inserm-02116055

\section{HAL Id: inserm-02116055 https://www.hal.inserm.fr/inserm-02116055}

Submitted on 22 Oct 2021

HAL is a multi-disciplinary open access archive for the deposit and dissemination of scientific research documents, whether they are published or not. The documents may come from teaching and research institutions in France or abroad, or from public or private research centers.
L'archive ouverte pluridisciplinaire HAL, est destinée au dépôt et à la diffusion de documents scientifiques de niveau recherche, publiés ou non, émanant des établissements d'enseignement et de recherche français ou étrangers, des laboratoires publics ou privés.

\section{(c) (1) $\$$}

Distributed under a Creative Commons Attribution - NonCommerciall 4.0 International 
Incidence and survival of peritoneal malignant mesothelioma between 1989 and 2015: a population-based study

N. Le Stang ${ }^{(a, b)}$, V. Bouvier ${ }^{(b, c, d)}$, O. Glehen ${ }^{(e)}$, L. Villeneuve $^{(e)}$, FRANCIM network $^{(b)}$, MESOPATH Referent National Center ${ }^{(f)}$, F. Galateau-Sallé(a,b,f), B. Clin ${ }^{(d, g)}$.

(a) Multicenter national mesothelioma registry (MESONAT), Léon Bérard Cancer Center, Lyon, F-69008, France

(b) FRANCIM Network, Toulouse, F-31000, France

(c) Digestive Cancer Registry, University Hospital, Caen, F-14033, France

(d) INSERM U1086 « ANTICIPE », Caen University, F-14000, Caen, France

(e) RENAPE Referent National Center, Hospices Civils de Lyon, Lyon, F-69010, France

(f) MESOPATH Referent National Center, Léon Bérard Cancer Center, Lyon, F-69008, France

(g) Occupational diseases department, University Hospital, Caen, F-14033, France

Members of FRANCIM network (solid tumors) are Simona Bara (Manche cancer registry), Véronique Bouvier (Calvados digestive cancer registry), Marc Colonna (Isère cancer registry), Gaëlle Coureau (Gironde cancer registry), Anne Cowppli-Bony (Loire-Atlantique \& Vendée cancer registry), Tania d'Almeida (Haute-Vienne cancer registry), Laetitia Daubisse-Marliac (Tarn cancer registry), Gautier Defossez (Poitou-Charentes cancer registry), Patricia Delafosse (Isère cancer registry), Pascale Grosclaude (Tarn cancer registry), Anne-Valérie Guizard (Calvados cancer registry), Sandrine Plouvier (Lille region cancer registry), Bénédicte LapotreLedoux (Somme cancer registry), Nolwenn Le Stang (MESONAT cancer registry), Emilie Marrer (Haut-Rhin cancer registry), Florence Molinié (Loire-Atlantique \& Vendée cancer registry), Brigitte Trétarre (Hérault cancer registry), Michel Velten (Bas-Rhin cancer registry), AnneSophie Woronoff (Doubs \& Belfort Territory cancer registry).

Members of MESOPATH Referent National Center are Issam Abd Alsamad (Hospital, Créteil), Hugues Begueret (University Hospital, Bordeaux), Elisabeth Brambilla (University Hospital, Grenoble), Frédérique Capron (University Hospital, Paris), Aurélie Cazès (University Hospital, Paris), Marie-Christine Copin (University Hospital, Lille), Diane Damotte (University Hospital, 
Paris), Claire Danel (University Hospital, Paris), Peggy Dartigues (Cancer Center, Villejuif), Anne-Yvonne de Lajartre (University Hospital, Nantes), Armelle Foulet-Rogé (Hospital, Le Mans), Françoise Galateau-Sallé (Cancer Center, Lyon), Louise Garbe (University Hospital, Marseille), Sophie Giusiano (University Hospital, Marseille), Odile Groussard (University Hospital, Paris), Véronique Hofman (University Hospital, Nice), Sylvie Isaac (University Hospital, Lyon), Sylvie Lantuejoul (Cancer Center, Lyon), Jean-Michel Picquenot (Cancer Center, Rouen), Gaëtane Planchard (University Hospital, Caen), Eliane Mery (University Hospital, Toulouse), Isabelle Rouquette (University Hospital, Toulouse), Christine Sagan (University Hospital, Nantes), Françoise Thivolet-Bejui (University Hospital, Lyon), Séverine Valmary-Degano (University Hospital, Besançon), Jean-Michel Vignaud (University Hospital, Nancy).

Corresponding Author:

Nolwenn LE STANG

MESONAT registry

Biopathology

Léon Bérard Cancer Center

28 rue Laënnec

69008 LYON, FRANCE

Phone: (33) 4698561 13; Fax: (33) 478782713

Email: nolwenn.lestang@1yon.unicancer.fr

\section{Abstract}

Background: Peritoneal malignant mesothelioma is a rare disease for which few populationbased studies are available. The aim of this study was to describe the evolution of the 
incidence and survival of peritoneal malignant mesothelioma in France between 1989 and 2015, using data derived from the French network of cancer registries.

Methods: Age world-standardized incidence rates and overall survival were calculated using data from 16 French cancer registries. Log-linear Poisson regression analysis was used to estimate the average annual percentage change in incidence rates. Overall survival was performed using age-adjusted Cox proportional hazards model.

Results: In French men, the incidence has increased quietly over the reporting period from 0.07 to 0.10 with a maximum of 0.16 per 100,000 persons-years in $2001-2003$. For women, the increase in incidence has been lower than for men over the period 1989-2015, ranging from 0.04 to 0.11 . A better prognosis was associated with a diagnosis made after 2000 ( $H R=$ 1.76; $p=0.013)$, the epithelioid histological type $(p=0.003)$, and the fact of being a woman, which has a 5 -year risk of death half that of men ( $H R=0.55 ; p=0.001)$, regardless of age, diagnosis period or histology.

Conclusion: Our results are similar to those currently available for other countries. In France, peritoneal mesothelioma remains a rare and fatal cancer with a small increase in the incidence rate since 1989 and a median survival of 1 year; it seemed to develop equally in women and men over this period of time.

Keywords: Malignant peritoneal mesothelioma, incidence, time trends, survival

\section{Introduction}

Malignant mesothelioma is a rare disease that results from the transformation of mesothelial cells that line the serosal surfaces. It represents $0.2 \%$ of all cancers [1] and has a dismal prognosis with few therapeutic options. Mesothelioma is much more frequent in men than in women (ratio 3.7:1) [2]. It is strongly associated with asbestos exposure (up to $90 \%$ of male cases [3]), and can develop in the pleura (the most frequent location, $90 \%$ ), the peritoneum (10\%), and rarely in the tunica vaginalis testis and pericardium [4].

Due to its rarity, trends in peritoneal mesothelioma among men and women are not as extensively described as for pleural mesothelioma. Between 1971 and 1995, the incidence of peritoneal mesothelioma was estimated to $0.02-0.3$ cases per 100,000 persons-years in the US and Europe. Age world-standardized rates per 100,000 persons-years range from 0.05-0.3 
cases in men to $0.02-0.2$ in women [5]. A study carried out in 2011, the RARECARE study, estimated the incidence between 1995 and 2002 at 0.12 cases per 100,000 persons-years in Europe [6].

The 5-year overall and relative survivals reported by the RARECARE study between 1995 and 2002 and were $9.8 \%$ and $11.4 \%$, respectively [6]. The mechanisms of carcinogenesis in peritoneal malignant mesothelioma have not been definitively elucidated [7], limiting the therapeutic options. Nevertheless, the combined treatment of cytoreductive surgery with hyperthermic intraperitoneal chemotherapy can offer prolonged survival for selected patients, increasing the 5-year overall survival to $47 \%$ [8].

Taking advantage of the French National Database MESOPATH, which systematically certifies the pathological diagnosis of mesothelioma, together with the French Network of Registries (FRANCIM), this study describes for the first time the French incidence and survival of malignant peritoneal mesothelioma from population-based data available between 1989 and 2015.

\section{Material and methods}

\subsection{Data sources}

FRANCIM provided incidence and follow-up data from local cancer registries operating at the 'department' level (French administrative area). All of these registries follow the rules of the European Network of Cancer Registries for recording and coding, and cancers were defined according to the International Classification of Diseases for Oncology, 3rd edition (ICDO-3). Local data were checked and standardized before inclusion in the common database [9]. Data were available from 16 registries of this network, with at least 5 years of information for the areas covered by the cancer registries, which in total represent $20 \%$ of the French metropolitan population (Table 1). The included invasive tumors corresponded to ICDO-3 C48.0-8 topographies and 9050/3-9053/3 morphologies, diagnosed between 1989 and 2015. A standardized procedure of certification for the pathological diagnosis is applied to all reported mesothelioma cases in France. The pathological diagnosis certification is provided by expert pathologists in the field covering all the French departments, the Referent National Center MESOPATH $[10,11]$. The cases were recorded according to the three histological types (epithelioid, biphasic and sarcomatoid) as defined by the WHO 2015 classification. The well- 
differentiated papillary mesotheliomas, multicystic peritoneal mesotheliomas, and adenomatoid tumors were all excluded from the study because they were clinically and prognostically separate entities from diffuse epithelioid malignant mesothelioma. They were indolent tumors associated with very long survival.

The population data estimated for each department each year for each age group were provided by the National Institute for Statistics and Economic Studies.

All registries carried out an active search for the vital status of the patients using a single standardized procedure via an electronic request to the 'National directory identifying private persons' and from the medical patient's files on June $30^{\text {th }} 2013$. For patients still alive, an update of the survival was made from the patient's medical files on September $30^{\text {th }} 2018$. The search for the context of asbestos exposure is not part of the collected data from the registries, and is not exhaustively reported in MESOPATH database.

\subsection{Statistical analysis}

All statistical analyses were performed using Stata Statistical Software: Release 13.0 (College Station, Texas, USA: Stata Corporation). Potential differences in individual and morphological characteristics were investigated by period using Pearson's chi-square and Mann-Whitney's tests.

The incidence rates by gender were estimated as the number of incident cases occurring each year divided by the total annual persons-years the same year in the general population in the same geographical area. Age-specific rates were calculated using 10-year age groups and 3year period groups. Age world-standardized rates were standardized by the direct method using the World population age structure proposed by Segi's reference [12] and were expressed for 100,000 persons-years. Changes in time trends were analyzed using ageadjusted log-linear Poisson regression.

For patients diagnosed between 1989 and 2012, we calculated the overall survival (OS) defined as the time between the date of diagnosis and the date of last follow-up, at 1, 3 and 5 years using the Kaplan-Meier method. Curves resulting from univariate analysis were compared by using the log-rank test. For multivariate analysis, the age-adjusted Cox proportional hazards model was used, significant variables in univariate analysis being entered $(p<0.15)$. 
For incidence and survival, rates and hazard ratios (HRs) are given with $95 \%$ confidence intervals $(95 \% \mathrm{Cls})$.

\section{Results}

\subsection{Incidence}

A total of 349 malignant peritoneal mesotheliomas diagnosed between January $1^{\text {st }} 1989$ and December $31^{\text {st }} 2015$ were used to calculate the incidence (Table 1). We found an almost equal incidence in men and women, with a ratio of men to women of $1.3(195 / 154)$. The median age of onset was 66 years; there was no significant difference between men (67 years) and women (65 years). The gender distribution $(p=0.51)$ and age of patients $(p=0.27)$ were the same in each diagnosis period. The diagnosis was more precise after 2000 due to the improving pathological knowledge of mesothelioma and the establishment of the pathological diagnosis certification, resulting in a significant decrease in the not-otherwise-specified mesothelioma percentage between 1989 and 2015 (Table 2).

Although the incidence rates for peritoneal mesothelioma increased over the period, no significant change in incidence was observed between 1989 and 2015. In men, the world agestandardized incidence rate increased weakly by $+0.94 \%(-1.04 \% ; 1.40 \%)$ per year over the overall period from 0.07 in 1989 to 0.10 in 2015. In women, with an incidence of 0.04 in 1989 against 0.07 in 2015, an increase of $+0.74 \%(-1.20 \%$; $1.37 \%)$ per year is reported (Figure 1 , Table 3). It should be noted that between 2004 and 2015 the trends in male and female incidence rates were very similar (Figure 1).

\subsection{Survival}

A total of 282 malignant peritoneal mesotheliomas diagnosed between January $1^{\text {st }} 1989$ and December $31^{\text {st }} 2012$ were used to calculate the survival (Table 1). The proportion of lost-tofollow-up cases was $1.7 \%$. The total population presented a median OS of 11.4 months and a 5 -year OS of $21 \%(95 \% \mathrm{Cl} 17-26)$.

In the univariate analysis, the 5-year OS was significantly lower for patients older than 66 years (11\%; 95\% Cl 5-19; $p<0.0001)$. Women had a better survival than men, with a 5 -year OS of $33 \%$ against $12 \%$ in men $(p<0.0001)$. A non-epithelioid histology was associated with a worse prognosis with a 5-year OS of 8\%. Epithelioid type and not-otherwise-specified mesothelioma had a survival of $23 \%$ at 5 years. Patients diagnosed in the more recent period 
had a better survival at 5 years: 31\% in the period $2010-2012$ against $18 \%$ in the periods 1989-1999 and 2000--2009 (Table 4). Survival at 5 years improved-especially during the last diagnostic period-in women (51\% in 2010-2012, 26\% in 1989-2009), in patients under 66 years of age (40-60\% in 2010-2012, 14-31\% in 1989-2009) and by histological type (Table 5).

The multivariate analysis adjusted by age confirmed the results of the univariate analysis. Women had a 5 -year risk of death half that of men ( $H R=0.55 ; p=0.001)$, regardless of age, diagnosis period or histology. A diagnosis made after 2000 also had half the 5-year risk of death $(H R=1.76 ; p=0.013)$. Biphasic or fibrous (sarcomatoid) mesotheliomas had for their part a risk at 5 years two-fold greater than that of epithelioid or not-otherwise-specified mesothelioma $(p=0.003)$ (Table 4).

\section{Discussion}

In this study we report for the first time the patients' characteristics and long-term trends in the incidence and survival of peritoneal malignant mesothelioma in France from the population-based cancer registries, using data available since 1989. Peritoneal mesothelioma is a rare disease that histologically mimics other cancers, causing frequent misdiagnosis that may result in epidemiological discordances. Thanks to advances in biological and histological knowledge of this tumor and the establishment in France in 1998 of a standardized procedure for certification of the diagnosis of mesothelioma, diagnostic accuracy has improved, as has in consequence the coding and assessment of incidence, reducing epidemiological bias [9]. In our series, the risk of misclassification is minimal.

We found that, contrary to pleural malignant mesothelioma (ratio of men to women of about 4:1 between 1989 and 2003 and 3:1 since 2003 [3,9,10,13-15]), peritoneal mesothelioma develops almost equally in both men and women. In French men, the incidence has been slowly increasing since 1989 from 0.07 per 100,000 persons-years in the period 1989-1991 to 0.10 in 2012-2015, with a maximum rate of 0.16 in 2001-2003. For women, this rate increased faster than for men over the period 1989-2015, fluctuating between 0.04 and 0.11 . These findings were consistent with results recently published in Europe [16]; in particular, the male incidence per 100,000 persons-years in Lombardy had two peaks, one in 2001 (0.17) and one in 2010 (0.19) [15], and this has also been observed in France. 
If we compare our results with those obtained in a parallel study of the pleural counterpart in similar population settings and data sources [9], we notice that the clinical behavior of these two mesothelioma localizations is clearly different. The median OS is 11.7 months in peritoneum and 10.6 months in pleura. Only $4 \%$ of men and $11 \%$ of women affected by pleural mesothelioma are alive 5 years after diagnosis, against $13 \%$ of men and $34 \%$ of women with peritoneal mesothelioma. The 1-year survival rate is similar for both diseases, reflecting the high lethality of these diseases regardless of their location; however, the proportion of long-term survivors is larger in peritoneal mesothelioma cases $[17,18]$. The main individual characteristics associated with 5-year survival, regardless of age, are: female gender, epithelioid morphology, and diagnosis after 2000. Regarding the results for the histological type, the devastating prognosis of biphasic or sarcomatoid types (also called fibrous for cancer registries) is well established [17-19].

Due to the appointment of a pathologists' panel at national level to perform a pathological review, we could rule out that diagnosis misclassification occurred selectively in women and is responsible for the difference in survival between genders. Several studies have reported the role of gender in prognosis $[17,20]$, which may reflect a biological difference. Recent molecular studies have provided new insights, in particular regarding the loss-of-function mutations in CDKN2A (p16), NF2 and BAP1 previously reported in pleural malignant mesothelioma [21-23]. The prognostic impact of these alterations was investigated in peritoneal mesothelioma [24-26]; it was found that the presence of a BAP1 mutation is a longterm survival factor, while the presence of homozygous CDKN2A deletion or hemizygous NF2 loss results in poor survival. Singhi et al. [25], in a series of 86 patients with peritoneal mesothelioma who benefited from cytoreductive surgery and hyperthermic intraperitoneal chemotherapy between 2001 and 2014, showed that peritoneal cancer index, extent of invasion, and combination of CDKN2A deletion and NF2 loss were prognostic factors independent of age. Gender and completeness of cytoreduction were not significant. However, there were no significant differences in the frequency of CDKN2A deletions, NF2 loss, and BAP1 expression between the 60 men and 26 women included in this study. The diagnosis period also seems to play an important role in the prognosis. Continuous advances in the knowledge of mesothelioma, and therefore in medical imaging, immunohistochemical and molecular biology techniques allow for more efficient and earlier detection of this disease. With the introduction of cytoreductive surgery and hyperthermic 
intraperitoneal chemotherapy, studies from the literature have reported significant improvement in survival for patients treated for a peritoneal mesothelioma $[8,27,28]$. In France, this heavy treatment has been performed on selected peritoneal mesothelioma patients since the early 1990s. Moreover, the French National Cancer Institute (INCa) supports the establishment of the RENAPE Network of expert and specialized centers in the management of this rare peritoneal disease in 2009. We may hypothesize that this policy leading to early diagnosis and better therapeutic management may explain the better prognosis in the most recent population (from 2010 to 2012). The RENAPE database [28,29] reported a median survival of 61 months and a 5 -year OS of $53 \%$ on a series of 126 eligible cases with a median age of 56-59 years diagnosed between 1991 and 2014 . According to the multivariate analysis performed, the only independent prognostic factors were the completeness of cytoreduction and the administration of neoadjuvant chemotherapy [30]. This study did not take into account molecular markers.

\section{Conclusions}

Our results are similar to those currently available for other countries. In France, peritoneal mesothelioma remains a rare and fatal cancer with a small increase in the incidence rate since 1989 and a median survival of 1 year. Noticeably, our results provide evidence that peritoneal mesothelioma develops equally in women and men over this period of time. More extensive epidemiological studies on larger cohorts would be needed for a better understanding of the trends in mesothelioma in relation to biological, occupational and non-occupational etiological factors.

\section{Acknowledgements}

The authors wish to thank Dr Lynnette Fernandez-Cuesta for the English language correction and critical suggestions, Professor Jean Yves Blay and Thierry Durand 'Cancer Center Leon Berard' for their support. and 'Santé Publique France' and 'Institut National du Cancer' for financial support to registries and Reference National Centers. 


\section{References}

[1] Bray F, Ferlay J, Soerjomataram I, Siegel RL, Torre LA, Jemal A. Global cancer statistics 2018: GLOBOCAN estimates of incidence and mortality worldwide for 36 cancers in 185 countries. CA Cancer J Clin. 2018 Sep 12.

[2] Abdel-Rahman O. Global trends in mortality from malignant mesothelioma: Analysis of WHO mortality database (1994-2013). Clin Respir J. 2018; 12(6): 2090-2100.

[3] Marinaccio A, Corfiati M, Binazzi A, Di Marzio D, Scarselli A, Ferrante P, Bonafede M, Verardo M, Mirabelli D, Gennaro V, Mensi C, Schallemberg G, Mazzoleni G, Merler E, Girardi P, Negro C, D'Agostin F, Romanelli A, Chellini E, Silvestri S, Pascucci C, Calisti R, Stracci F, Romeo E, Ascoli V, Trafficante L, Carrozza F, Angelillo IF, Cavone D, Cauzillo G, Tallarigo F, Tumino R, Melis M, Iavicoli S; ReNaM Working Group. The epidemiology of malignant mesothelioma in women: gender differences and modalities of asbestos exposure. Occup Environ Med. 2018; 75(4): 254-262.

[4] Galateau-Sallé F, Brambilla E, Cagle P, et al. Pathology of malignant mesothelioma; an update of the international mesothelioma panel. London: Springer, 2006. p. 29.

[5] Boffetta P, Epidemiology of peritoneal mesothelioma: a review, Ann. Oncol. 2007; 18: 985-990.

[6] Gatta G, van der Zwan JM, Gasali PG, Siesling S, Dei Tos AP, Kunkler I, et al. Rare cancers are not so rare: the rare cancer burden in Europe, Eur J Cancer. 2011; 47: 2493-2511. doi: 10.1016/j.ejca.2011.08.008.

[7] Judge S, Thomas P, Govindarajan V, Sharma P, Loggie B. Malignant peritoneal mesothelioma: characterization of the inflammatory response in the tumor microenvironment, Ann Surg Oncol. 2016; 23: 1496-1500. doi: 10.1245/s10434-015-4965-6.

[8] Yan TD, Deraco M, Baratti D et al. Cytoreductive surgery and hyperthermic intraperitoneal chemotherapy for malignant peritoneal mesothelioma: multiinstitutional experience. J Clin Oncol 2009; 27: 6237-6242. doi: 10.1200/JCO.2009.23.9640. 
[9] Cowppli-Bony A, Uhry Z, Remontet L, Voirin N, Guizard AV, Trétarre B, Bouvier AM, Colonna M, Bossard N, Woronoff AS, Grosclaude P; French Network of Cancer Registries (FRANCIM). Survival of solid cancer patients in France, 1989-2013: a populationbased study. Eur J Cancer Prev. 2017; 26(6): 461-468. doi: 10.1097/CEJ.0000000000000372.

[10] Le Stang N, Belot A, Gilg Soit Ilg A, Rolland P, Astoul P, Bara S, Brochard P, Danzon A, Delafosse P, Grosclaude P, Guizard AV, Imbernon E, Lapôtre-Ledoux B, Ligier K, Molinié F, Pairon JC, Sauleau EA, Trétarre B, Velten M, Bossard N, Goldberg M, Launoy G, GalateauSallé F. Evolution of pleural cancers and malignant pleural mesothelioma incidence in France between 1980 and 2005. Int J Cancer. 2010; 126(1): 232-8.

[11] Galateau-Sallé F, Gilg Soit Ilg A, Le Stang N, Brochard P, Pairon JC, Astoul P, Frenay C, Blaizot G, Chamming's S, Ducamp S, Rousvoal T, de Quillacq A, Abonnet V, Abdalsamad I, Begueret H, Brambilla E, Capron F, Copin MC, Danel C, de Lajartre AY, Foulet-Roge A, Garbe L, Groussard O, Giusiano S, Hofman V, Lantuejoul S, Piquenot JM, Rouquette I, Sagan C, Thivolet-Bejui F, Vignaud JM, Scherpereel A, Jaurand MC, Jean D, Hainaut P, ChériéChalline L, Goldberg M, Luce D, Imbernon E. The French mesothelioma network from 1998 to 2013. Ann Pathol. 2014; 34(1): 51-63. doi: 10.1016/j.annpat.2014.01.009.

[12] Segi M, Fukushima I, Kurihara M. A proposal on a calculation method to be applied by geographical comparison of cancer mortality. Tohoku J Exp Med. 1954; 60(3-4): 307-10.

[13] Gilg Soit Ilg A, Ducamp S, Gramond C, Audignon S, Chamming's S, de Quillacq A, et al. Programme national de surveillance du mésothéliome (PNSM). Actualisation des principaux résultats. Bull Epidémiol Hebd. 2015; (3-4): 28-37. http://www.invs.sante.fr/beh/2015/3-4/2015_3-4_1.html

[14] Salo SAS, Ilonen I, Laaksonen S, Myllärniemi M, Salo JA, Rantanen T. Epidemiology of malignant peritoneal mesothelioma: A population-based study. Cancer Epidemiol. 2017; 51: 81-86. doi: 10.1016/j.canep.2017.10.008. Epub 2017 Nov 5. PubMed PMID: 29080447. 
[15] Mensi C, Mendola M, Dallari B, Sokooti M, Tabibi R, Riboldi L, Consonni D. Differences between peritoneal and pleural mesothelioma in Lombardy, Italy. Cancer Epidemiol. 2017; 51: 68-73. doi: 10.1016/j.canep.2017.10.003.

[16] Siesling S, van der Zwan JM, Izarzugaza I, Jaal J, Treasure T, Foschi R, Ricardi U, Groen H, Tavilla A, Ardanaz E; RARECARE Working Group. Rare thoracic cancers, including peritoneum mesothelioma. Eur J Cancer. 2012; 48(7): 949-60. doi: 10.1016/j.ejca.2012.02.047.

[17] Mirabelli D, Roberti S, Gangemi M, Rosato R, Ricceri F, Merler E, Gennaro V, Mangone L, Gorini G, Pascucci C, Cavone D, Nicita C, Barbieri PG, Marinaccio A, Magnani C, Montanaro F. Survival of peritoneal malignant mesothelioma in Italy: a population-based study. Int J Cancer. 2009; 124(1): 194-200. doi: 10.1002/ijc.23866.

[18] Montanaro F, Rosato R, Gangemi M, Roberti S, Ricceri F, Merler E, Gennaro V, Romanelli A, Chellini E, Pascucci C, Musti M, Nicita C, Barbieri PG, Marinaccio A, Magnani C, Mirabelli D. Survival of pleural malignant mesothelioma in Italy: a population-based study. Int J Cancer. 2009; 124(1): 201-7. doi: 10.1002/ijc.23874. PubMed PMID: 18792097.

[19] Soeberg MJ, Leigh J, Driscoll T, Armstrong B, Young JM, van Zandwijk N. Incidence and survival trends for malignant pleural and peritoneal mesothelioma, Australia, 1982-2009. Occup Environ Med. 2016; 73(3): 187-94. doi: 10.1136/oemed-2015-103309.

[20] Cao C, Yan TD, Deraco M, Elias D, Glehen O, Levine EA, Moran BJ, Morris DL, Chua TC, Piso P, Sugarbaker PH; Peritoneal Surface Malignancy Group. Importance of gender in diffuse malignant peritoneal mesothelioma. Ann Oncol. 2012; 23(6): 1494-8. doi: 10.1093/annonc/mdr477.

[21] Bueno R, Stawiski EW, Goldstein LD, Durinck S, De Rienzo A, Modrusan Z, Gnad F, Nguyen TT, Jaiswal BS, Chirieac LR, Sciaranghella D, Dao N, Gustafson CE, Munir KJ, Hackney JA, Chaudhuri A, Gupta R, Guillory J, Toy K, Ha C, Chen YJ, Stinson J, Chaudhuri S, Zhang N, Wu TD, Sugarbaker DJ, de Sauvage FJ, Richards WG, Seshagiri S. 
Comprehensive genomic analysis of malignant pleural mesothelioma identifies recurrent mutations, gene fusions and splicing alterations. Nat Genet. 2016; 48(4): 407-16. doi: 10.1038/ng.3520.

[22] Guo G, Chmielecki J, Goparaju C, Heguy A, Dolgalev I, Carbone M, Seepo S, Meyerson M, Pass HI. Whole-exome sequencing reveals frequent genetic alterations in BAP1, NF2, CDKN2A, and CUL1 in malignant pleural mesothelioma. Cancer Res. 2015; 75(2): 2649. doi: 10.1158/0008-5472.CAN-14-1008.

[23] De Rienzo A, Archer MA, Yeap BY, Dao N, Sciaranghella D, Sideris AC, Zheng Y, Holman AG, Wang YE, Dal Cin PS, Fletcher JA, Rubio R, Croft L, Quackenbush J, Sugarbaker PE, Munir KJ, Battilana JR, Gustafson CE, Chirieac LR, Ching SM, Wong J, Tay LC, Rudd S, Hercus R, Sugarbaker DJ, Richards WG, Bueno R. Gender-Specific Molecular and Clinical Features Underlie Malignant Pleural Mesothelioma. Cancer Res. 2016; 76(2): 31928. doi: 10.1158/0008-5472.CAN-15-0751.

[24] Singhi AD, Krasinskas AM, Choudry HA, Bartlett DL, Pingpank JF, Zeh HJ, Luvison A, Fuhrer K, Bahary N, Seethala RR, Dacic S. The prognostic significance of BAP1, NF2, and CDKN2A in malignant peritoneal mesothelioma. Mod Pathol. 2016; 29(1): 14-24. doi: 10.1038/modpathol.2015.121.

[25] Leblay N, Leprêtre F, Le Stang N, Gautier-Stein A, Villeneuve L, Isaac S, Maillet D, Galateau-Sallé F, Villenet C, Sebda S, Goracci A, Byrnes G, McKay JD, Figeac M, Glehen O, Gilly FN, Foll M, Fernandez-Cuesta L, Brevet M. BAP1 Is Altered by Copy Number Loss, Mutation, and/or Loss of Protein Expression in More Than 70\% of Malignant Peritoneal Mesotheliomas. J Thorac Oncol. 2017; 12(4): 724-733. doi: 10.1016/j.jtho.2016.12.019.

[26] Baumann F, Flores E, Napolitano A, Kanodia S, Taioli E, Pass H, Yang H, Carbone M. Mesothelioma patients with germline BAP1 mutations have 7-fold improved long-term survival. Carcinogenesis. 2015; 36(1): 76-81. doi: 10.1093/carcin/bgu227. 
[27] Malgras B, Gayat E, Aoun O, Lo Dico R, Eveno C, Pautrat K, Delhorme JB, Passot G, Marchal F, Sgarbura O, Ferron G, Goéré D, Andre T, Pocard M; RENAPE Network. Impact of Combination Chemotherapy in Peritoneal Mesothelioma Hyperthermic Intraperitoneal Chemotherapy (HIPEC): The RENAPE Study. Ann Surg Oncol. 2018; 25(11): 3271-3279. doi: 10.1245/s10434-018-6631-2.

[28] Villeneuve L, Passot G, Glehen O, Isaac S, Bibeau F, Rousset P, Gilly FN; RENAPE Network. The RENAPE observational registry: rationale and framework of the rare peritoneal tumors French patient registry. Orphanet J Rare Dis. 2017;12(1):37. doi: 10.1186/s13023-0170571-y.

[29] Villeneuve L, Isaac S, Glehen O, Capovilla M, Chevallier A, Croce S, Dartigues P, Fontaine J, Kaci R, Lang-Averous G, Laverriere MH, Leroux-Broussier A, Mery E, Poizat F, Valmary-Degano S, Verriele-Beurrier V, Gilly FN, Bibeau F. The RENAPE network: towards a new healthcare organization for the treatment of rare tumors of the peritoneum. Description of the network and role of the pathologists. Ann Pathol. 2014;34(1):4-8. doi: 10.1016/j.annpat.2014.01.008.

[30] Kepenekian V, Elias D, Passot G, Mery E, Goere D, Delroeux D, Quenet F, Ferron G, Pezet D, Guilloit JM, Meeus P, Pocard M, Bereder JM, Abboud K, Arvieux C, Brigand C, Marchal F, Classe JM, Lorimier G, De Chaisemartin C, Guyon F, Mariani P, Ortega-Deballon P, Isaac S, Maurice C, Gilly FN, Glehen O; French Network for Rare Peritoneal Malignancies (RENAPE). Diffuse malignant peritoneal mesothelioma: Evaluation of systemic chemotherapy with comprehensive treatment through the RENAPE Database: Multi-Institutional Retrospective Study. Eur J Cancer. 2016; 65: 69-79. doi: 10.1016/j.ejca.2016.06.002. 
Figure 1. Trends in malignant peritoneal mesothelioma in world age-standardized incidence rates per 100,000 persons-years. 


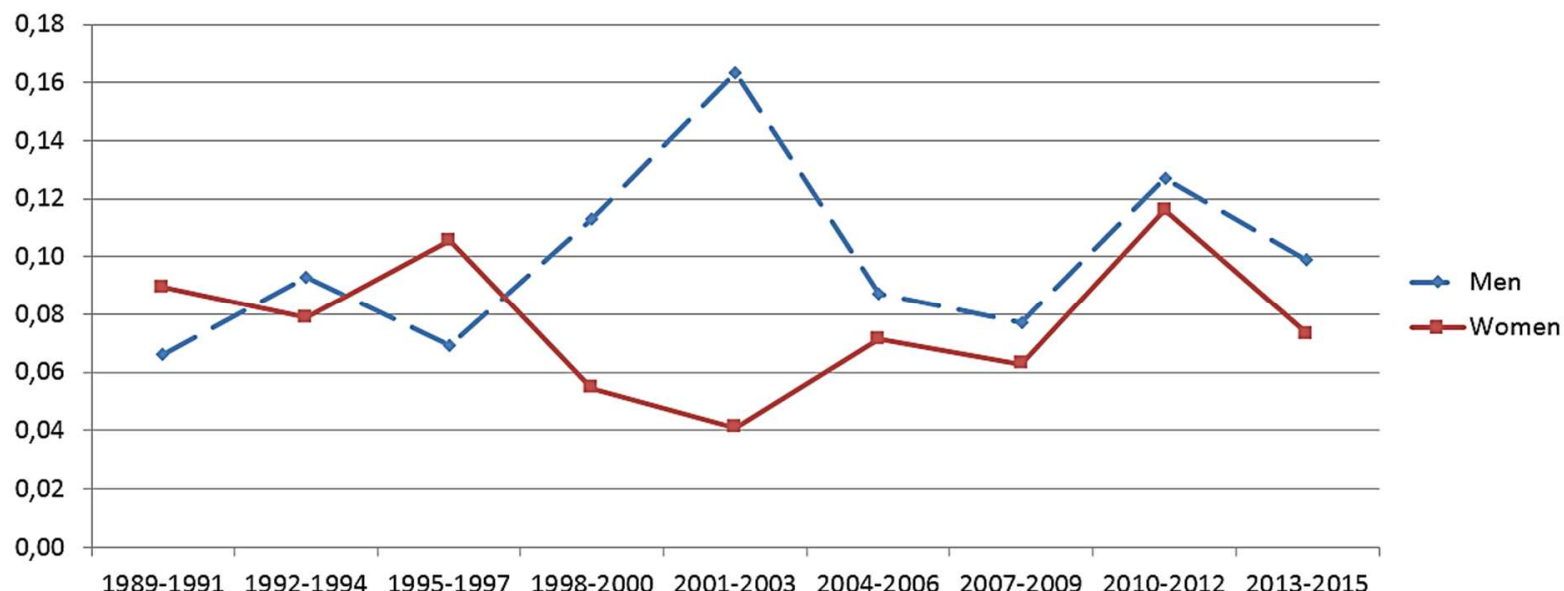

$\begin{array}{llllllll}1989-1991 & 1992-1994 & 1995-1997 & 1998-2000 & 2001-2003 \quad 2004-2006 \quad 2007-2009 & 2010-2012 \quad 2013-2015\end{array}$ 
Table 1. Data sources of incidence and survival of peritoneal malignant mesothelioma.

\begin{tabular}{|c|c|c|c|c|c|}
\hline \multirow{2}{*}{$\begin{array}{l}\text { Geographical } \\
\text { coverage }\end{array}$} & \multicolumn{3}{|c|}{ Incidence } & \multicolumn{2}{|c|}{ Survival } \\
\hline & $\begin{array}{c}\text { Population } \\
\text { (estimates 2015) }\end{array}$ & $\begin{array}{l}\text { Diagnosis } \\
\text { period }\end{array}$ & $\begin{array}{l}\text { Number } \\
\text { of cases }\end{array}$ & Diagnosis period & $\begin{array}{l}\text { Number } \\
\text { of cases }\end{array}$ \\
\hline Bas-Rhin & $1,116,658$ & 1989-2015 & 31 & 1989-2012 & 29 \\
\hline Calvados & 639,938 & 1989-2015 & 42 & 1989-2012 & 37 \\
\hline Doubs & 536,959 & 1989-2015 & 26 & 1989-2012 & 21 \\
\hline Gironde & $1,548,478$ & $2005,2008-15$ & 16 & $2005,2008-12$ & 10 \\
\hline Haut-Rhin & 762,607 & 1989-2015 & 16 & 1989-2012 & 15 \\
\hline Haute-Vienne & 375,795 & 2009-2015 & 2 & 2009-2012 & 1 \\
\hline Hérault & $1,120,190$ & 1989-2015 & 33 & 1989-2012 & 24 \\
\hline Isère & $1,251,060$ & 1989-2015 & 50 & 1989-2012 & 40 \\
\hline Lille et sa région & 793,603 & $2005,2008-15$ & 7 & $2005,2008-12$ & 4 \\
\hline Loire-Atlantique & $1,365,227$ & 1998-2015 & 38 & 1998-2012 & 30 \\
\hline Manche & 499,287 & 1994-2015 & 19 & $1994-2012$ & 15 \\
\hline Poitou-Charentes & $1,802,873$ & 2008-2015 & 18 & 2008-2012 & 15 \\
\hline Somme & 571,879 & 1989-2015 & 16 & 1989-2012 & 15 \\
\hline Tarn & 386,543 & 1989-2015 & 14 & 1989-2012 & 12 \\
\hline Territoire de Belfort & 144,483 & $2007-2015$ & 3 & 2007-2012 & 2 \\
\hline Vendée & 666,714 & $1998-2015$ & 18 & 1998-2012 & 12 \\
\hline Total & & & 349 & & 282 \\
\hline
\end{tabular}


Table 2. Patients' characteristics according to the diagnosis period.

\begin{tabular}{|c|c|c|c|c|c|}
\hline Variables & $\begin{array}{c}1989-2015 \\
n=349\end{array}$ & $\begin{array}{c}1989-1999 \\
n=86\end{array}$ & $\begin{array}{c}2000-2009 \\
n=125\end{array}$ & $\begin{array}{c}2010-2015 \\
n=138\end{array}$ & $\begin{array}{c}\text { Comparison } \\
\text { test }\end{array}$ \\
\hline Gender & & & & & $\mathrm{p}=0.51^{\mathrm{a}}$ \\
\hline Men & 195 (56\%) & $44(51 \%)$ & $74(59 \%)$ & 77 (56\%) & \\
\hline Women & 154 (44\%) & $42(49 \%)$ & $51(41 \%)$ & $61(44 \%)$ & \\
\hline Age & & & & & $p=0.27^{b}$ \\
\hline Median & $66 y$ & $65 y$ & $70 y$ & $65 y$ & \\
\hline Range & {$[20 ; 91]$} & {$[26 ; 88]$} & {$[20 ; 91]$} & {$[21 ; 87]$} & \\
\hline Age of men & & & & & $p=0.91^{b}$ \\
\hline Median & $67 y$ & $65 y$ & 69 y & 66 y & \\
\hline Range & {$[21 ; 88]$} & {$[26 ; 88]$} & {$[22 ; 88]$} & {$[21 ; 86]$} & \\
\hline Age of women & & & & & $p=0.18^{b}$ \\
\hline Median & $65 y$ & 64 y & $70 y$ & 64 y & \\
\hline Range & {$[20 ; 91]$} & {$[30 ; 83]$} & {$[20 ; 91]$} & {$[31 ; 87]$} & \\
\hline Histology & & & & & $\mathrm{P}<0.0001^{\mathrm{a}}$ \\
\hline Epithelioid $(9052 / 3)$ & $228(65 \%)$ & $41(48 \%)$ & 79 (63\%) & $108(78 \%)$ & \\
\hline Biphasic $(9053 / 3)$ & $232(7 \%)$ & $5(6 \%)$ & $7(5 \%)$ & $11(8 \%)$ & \\
\hline Fibrous (9051/3) & $8(2 \%)$ & $0(0 \%)$ & $6(5 \%)$ & $2(2 \%)$ & \\
\hline $\operatorname{NOS}(9050 / 3)$ & $90(26 \%)$ & $40(46 \%)$ & $33(27 \%)$ & $17(12 \%)$ & \\
\hline
\end{tabular}

NOS, not otherwise specified.

a Pearson $x^{2}$ test.

${ }^{\mathrm{b}}$ Mann-Whitney test. 
Table 3. World age-standardized incidence rates (with 95\%CIs) of malignant peritoneal mesothelioma per 100,000 persons-years between 1989 and 2015 .

\begin{tabular}{llccccccccc}
\hline Gender & Period & $1989-1991$ & $1992-1994$ & $1995-1997$ & $1998-2000$ & $2001-2003$ & $2004-2006$ & $2007-2009$ & $2010-2012$ & $2013-2015$ \\
\hline \multirow{2}{*}{ Men } & Rate & 0.07 & 0.09 & 0.07 & 0.11 & 0.16 & 0.09 & 0.07 & 0.13 & 0.10 \\
& $95 \% \mathrm{Cl}$ rate & {$[0.01-0.13]$} & {$[0.03-0.16]$} & {$[0.02-0.12]$} & {$[0.05-0.17]$} & {$[0.07-0.24]$} & {$[0.04-0.13]$} & {$[0.03-0.12]$} & {$[0.06-0.20]$} & {$[0.05-0.15]$} \\
\hline \multirow{2}{*}{ Women } & Rate & 0.09 & 0.08 & 0.10 & 0.05 & 0.04 & 0.07 & 0.06 & 0.11 & 0.07 \\
& $95 \% \mathrm{Cl}$ rate & {$[0.01-0.17]$} & {$[0.03-0.14]$} & {$[0.03-0.18]$} & {$[0.01-0.10]$} & {$[0.01-0.07]$} & {$[0.02-0.11]$} & {$[0.02-0.10]$} & {$[0.05-0.18]$} & {$[0.04-0.11]$} \\
\hline
\end{tabular}


Table 4. Results of univariate and multivariate analysis in overall survival.

\begin{tabular}{|c|c|c|c|c|c|c|c|}
\hline & \multicolumn{4}{|c|}{ Univariate analysis } & \multirow[b]{2}{*}{$\begin{array}{l}\text { Log-rank } \\
\text { test }\end{array}$} & \multicolumn{2}{|c|}{ Age-adjusted Cox model } \\
\hline & $\mathrm{n}$ & $\begin{array}{c}1 \text { 1-year OS } \\
{[95 \% \mathrm{Cl}]}\end{array}$ & $\begin{array}{c}\text { 3-year OS } \\
{[95 \% \mathrm{Cl}]}\end{array}$ & $\begin{array}{c}\text { 5-year OS } \\
{[95 \% \mathrm{Cl}]}\end{array}$ & & $\mathrm{HR}[95 \% \mathrm{Cl}]$ & $p$-value \\
\hline Age (years) & & & & & $p<0.0001$ & - & \\
\hline$<55$ & 73 & 76 [64-84] & 51 [39-62] & 38 [27-49] & & - & \\
\hline $55-65$ & 66 & $56[43-67]$ & 35 [24-46] & $26[16-37]$ & & - & \\
\hline $66-74$ & 74 & $37[26-48]$ & $18[10-27]$ & $11[5-19]$ & & - & \\
\hline$\geq 75$ & 65 & $23[14-34]$ & $12[6-22]$ & 9 [4-18] & & - & \\
\hline Gender & & & & & $p<0.0001$ & & $p=0.001$ \\
\hline Men & 158 & 40 [33-48] & 21 [14-27] & $12[8-18]$ & & $1.00^{\mathrm{a}}$ & - \\
\hline Women & 121 & 59 [50-67] & $41[32-49]$ & 33 [25-42] & & $0.55[0.39-0.77]$ & \\
\hline Diagnosis period & & & & & $p=0.07$ & & \\
\hline 1989-1999 & 86 & 41 [30-52] & 25 [16-35] & 18 [10-27] & & $1.76[1.13-2.74]$ & $p=0.013$ \\
\hline 2000-2009 & 124 & $48[38-56]$ & $29[21-37]$ & $18[12-25]$ & & $1.16[0.80-1.67]$ & $p=0.22$ \\
\hline 2010-2012 & 72 & $58[46-68]$ & 35 [24-46] & $31[21-42]$ & & $1.00^{\mathrm{a}}$ & \\
\hline Epithelioid & & & & & $p=0.03$ & & \\
\hline No & 25 & 31 [15-49] & 19 [7-36] & 8 [1-22] & & $2.00[1.27-3.15]$ & $p=0.003$ \\
\hline Yes & 176 & 53 [45-60] & 32 [25-39] & 23 [17-29] & & $1.00^{*}$ & \\
\hline NOS & 77 & 45 [34-55] & 27 [18-37] & 23 [14-33] & & 1.00 & \\
\hline
\end{tabular}

HR, hazard ratio; NOS, not otherwise specified; OS, overall survival.

a Reference class, 
Table 5. Overall survival at 1, 3 and 5 years by diagnosis period (in percentages).

\begin{tabular}{|c|c|c|c|c|c|c|c|c|c|c|c|c|}
\hline & \multicolumn{4}{|c|}{ 1989-1999 } & \multicolumn{4}{|c|}{ 2000-2009 } & \multicolumn{4}{|c|}{ 2010-2012 } \\
\hline & $\mathrm{n}$ & 1-year OS & 3-year OS & 5-year-OS & $\mathrm{n}$ & 1-year OS & 3-year OS & 5-year OS & $\mathrm{n}$ & 1-year OS & 3-year OS & 5-year-OS \\
\hline \multicolumn{13}{|l|}{ Gender } \\
\hline Men & 43 & 29 [16-43] & 14 [6-27] & $10[3-21]$ & 74 & 42 [31-53] & 25 [15-35] & 12 [6-21] & 41 & 49 [33-63] & 20 [9-33] & 15 [6-27] \\
\hline Women & 39 & 55 [38-69] & 37 [22-52] & 26 [13-41] & 50 & 55 [40-68] & 35 [22-48] & 26 [15-39] & 35 & 69 [50-81] & 54 [36-69] & 51 [33-66] \\
\hline \multicolumn{13}{|l|}{ Age $(y)$} \\
\hline$<55$ & 21 & 62 [38-79] & 43 [22-62] & 29 [12-48] & 32 & 75 [56-87] & 47 [29-63] & 31 [16-47] & 21 & 90 [67-98] & 66 [41-82] & 60 [36-78] \\
\hline $55-65$ & 25 & 52 [31-69] & 32 [15-50] & 24 [10-42] & 22 & 48 [26-67] & 29 [12-48] & 14 [4-32] & 20 & 70 [45-85] & 45 [23-65] & 40 [19-60] \\
\hline $66-74$ & 19 & 28 [10-49] & $11[2-30]$ & 6 [0-22] & 36 & $42[26-57]$ & 25 [12-40] & $14[5-27]$ & 19 & $37[17-57]$ & 11 [2-28] & 11 [2-28] \\
\hline$\geq 75$ & 17 & 12 [2-33] & 6 [0-25] & 6 [0-25] & 34 & 27 [14-43] & 15 [5-29] & 12 [4-26] & 16 & $31[11-54]$ & 25 [8-47] & 19 [5-40] \\
\hline \multicolumn{13}{|c|}{ Epithelioid type } \\
\hline No & 5 & 20 [1-58] & - & - & 13 & 23 [5-47] & 23 [5-47] & - & 8 & 50 [15-77] & 25 [4-56] & 25 [4-56] \\
\hline Yes & 39 & $41[25-56]$ & 30 [16-45] & 19 [8-33] & 79 & 56 [45-67] & 32 [22-42] & 20 [12-30] & 59 & 56 [42-67] & 33 [21-45] & $28[17-40]$ \\
\hline NOS & 38 & 45 [29-60] & 24 [12-38] & 18 [8-32] & 32 & 35 [19-52] & $23[10-38]$ & 19 [8-35] & 9 & 78 [36-94] & 56 [20-80] & 56 [20-80] \\
\hline
\end{tabular}

NOS, not otherwise specified; OS, overall survival. 